\title{
Customers' Perceptions about Plastic Money towards Sustainable Banking in Bangladesh: A Technological Adoption
}

\author{
Md. Al-Amin ${ }^{1}$, Nahida Sultana ${ }^{2}$, Shohel Md. Nafi ${ }^{3}$, SM Nazrul Islam ${ }^{4}$ \\ ${ }^{1}$ Lecturer, Department of Management Information Systems, Noakhali Science and Technology University \\ (NSTU), Noakhali, Bangladesh \\ ${ }^{2}$ Lecturer, Department of Business Administration, Bangladesh University, Dhaka, Bangladesh \\ ${ }^{3}$ Lecturer, Department of Tourism and Hospitality Management, Noakhali Science and Technology University \\ (NSTU), Noakhali, Bangladesh \\ ${ }^{4}$ Associate Professor, Department of Business Administration, Noakhali Science and Technology University \\ (NSTU), Noakhali, Bangladesh \\ Correspondence: Md. Al-Amin, Lecturer, Department of Management Information Systems, Noakhali Science \\ and Technology University (NSTU), Noakhali-3814, Bangladesh. E-mail: alamin.mis.du0618@gmail.com
}

Received: April 24, 2019

Accepted: May 20, 2019

Online Published: May 24, 2019

doi:10.5539/ibr.v12n6p82

URL: https://doi.org/10.5539/ibr.v12n6p82

\begin{abstract}
To build up a sustainable banking environment, technological implementation is crucial. As a part of this, modern banks propelled plastic money. In Bangladesh, customers' perceptions about the plastic money are impressive. This is the necessity to the banks what factors influence customers positive view toward plastic money and whether they are facing any problems or not. To examine the customers' perceptions towards plastic money is one of the main focuses of this research. About 200 responses were collected to conduct the study. A quantitative research design was adopted to perform the test of hypotheses. The survey results revealed that usage and financial benefits, convenience factors, and psychological factors positively influence customers' attitude towards plastic money. Also, there are some problems identified by the respondents as customers.
\end{abstract}

Keywords: plastic money, customer perception, sustainability, bank, Bangladesh

\section{Introduction}

More regularly, we are progressively reliant on new innovations to make our transactions quick and productive. The proceeded and fast development of innovation has achieved noteworthy changes in our regular day to day existences (Panagiotis et al., 2018). Plastic money is a contemporary mode of payment system that is noticeably changing the traditional idea of payment system through cash. Today's competition in the banking sectors has pushed banks to reconsider to discover substitute products in banking functions at minimum cost. Plastic money is helpful for banks as it enhances banks productivity and enhances the delivery of good services to their clients (Kaur \& Sharma, 2017).Every financial institution is utilizing this technique, forcefully promising all their clients to take the benefits of these systems on the grounds of straightforwardness process however an unannounced money related age to the bank (Odusina \& Ayokunle Olumide, 2014). Today customers cannot perform their banking functions without having a plastic card. The plastic money reduces difficulties of carrying cash at hand and minimizes the risk of theft. Recently, banks are providing different types of plastic money cards according to their customer demands e.g., debit card, credit card, visa card, and master card. The credit cards mitigate the clients from the stress of carrying cash and guarantees security. It is the comfort of broadened credit without custom (Sunayna Khurana \& Satendra Pal Singh, 2011). Now-a-days, bank provides plastic card to their customers which changed the setting of banking system in Bangladesh. The development of plastic money industry was very evident as individuals is getting more reliant on technology and plastic money business is the best result of technological innovation in banking sectors (Sumi \& Safiullah, 2014). The objective of our study is to analyze the customer's attitude toward plastic money in Bangladesh. We have some specific objectives like discover perceive advantages of Plastic money to the customers, identify perceived disadvantages to the customers and scrutinize the psychological and attitudinal factors of customers for plastic money usage. 


\section{Research Objectives}

The broad objective of this study is to analyze the consumer attitude towards plastic money. The specific objective is to:

- discover perceived advantages of plastic money to the customers

- identify perceived disadvantages of plastic money to the customers

\section{Research Implications:}

There are insufficient literatures found about the plastic money as a technological adoption towards sustainable banking in Bangladesh. Moreover, customer attitudes over the usage of plastic money have not yet been widely studied in a developing country - Bangladesh.

This study will provide notion about the bank's customers' perceptions regarding plastic money that will eventually assist them both in knowing the effectiveness of technological implication towards sustainable banking and customer satisfaction. Along with this, the results of this study will show implication for the banks to fix the problems in existing electronic trading devices through analyzing perceived disadvantages faced by customers.

\section{Literature Review}

Customer satisfaction is one of the major concerns for all kind of activities of a business organization. Almost every business organization tries to make a loyal customer base in the market to get a competitive advantage over other organization. Basically, customer satisfaction is the vital issue for the service industries like banking, health, restaurant, education etc. for their success. Bennet (1992) found that customer driven strategy is the major factor to gain competitive advantage in the banking sector. According to Coldwell (2011), a customer who is fully satisfied may support a firm to produce 2.6 times much revenue as the one who is somehow satisfied. Moreover, a completely disappointed customer may cause a 1.8 times reduce in revenue as compared to a fully satisfied customer. However, commercial banks have performed various functions for the customers and plastic money is the most vital and modern function (Deviranjitham \& Thamilarasan, 2014).

Plastic money is a contemporary context taking place of conventional system of paying through paper moneycash. The use of debit cards, credit cards, smart cards, master cards, visa cards, pre-paid balance cards for paying to purchase goods and services is termed as plastic money (Panagiotis, Athanasios \& others, 2018). Basically, plastic money means one kind of hard plastic card that has been used in place of bank notes and in everyday life (Sudhakar, 2014). The customer's buying behavior and lifestyle is now dominated by the plastic card. The plastic money can be defined as an electronic element which stocks all required information about the particular bank and the card holder and can be accomplished through the use of Automated Teller Machine (ATM) at any place. Moreover, Khan (2010) stated the impact of ATM service quality on customers using five key ATM service quality factors: convenience, efficient operation, security and privacy, reliability and responsiveness.

Money is always considered as a necessary medium for exchange and payment methods. In the recent years, money has turned its form from coins to paper cash and in the recent time money is usable in shapeless form as plastic money which is also called electronic money (Bishty et. al., 2015). Now-a-days, banking sector has changed their overall systems from traditional system to modern technology driven system. Plastic card facility has incorporated technology with the need of credit by the customers (Hugar \& Basavaraj, 2014). Some study stated that consumer satisfaction was calculated by functional and technical conditions in the banking industry (Gronroos, 1984).

Panagiotis et al. (2018) had thrown light on the use of new technology by elderly people contributing significantly on their better quality life. The usage of innovative electronic trading devices defend the elderly population from theft and fake cases since such cards in his/her wallet can be used immediately and easily in each transaction.

Diza et al. (2017) focused on plastic money acceptance among rural communities in Zimbabwe. The communities still prefer cash over plastic money, although they cited 'anytime anywhere access as major advantage of plastic money. They concluded the greatest challenges of plastic money usage in rural area include higher transaction costs and lack of POS facilities and also lack of confidence in entire banking sector.

Jonker (2007) mentioned that the "reason for the increase in the use of plastic cards is because plastic money provides consumers with convenience, ease of use, record of transaction, transaction speed, dispute resolution capability, and reliability among other benefits hence the growing preference towards the adoption of plastic 
cards". The most of the customers use and prefer to have plastic money above cash money. These plastic money or electronic payments was and used only by higher income group people (Manivannan, 2013).

Most of the customers like to use debit card rather than credit card for their transactions. Generally customers' like to use debit card for buying appeals, paying electricity bills or phone bills and others financial transactions. Many customers feel that debit card is more favorable than credit card because debit card provides more control over spending, good cash back policy and strong security. Moreover, majority of plastic money users use it for online transaction as they feel secure transaction in online but they completely avoid it when they use it for others financial activities (Bishty et. al., 2015).

According to Sumi and Safiullah (2014), with the technological revolution in financial sector, transactions in banking sector has brought a revolutionary change in Bangladesh. The various types of plastic money provided by the Bangladeshi banks like debit card, credit card, master card or visa card for their respective customers. The study showed that the usage of plastic cards in Bangladeshi banks and also showed the problems faced by the user of these cards. They also stated that customers have strong preference to accept plastic card rather than cash in hand.

\section{i. Usage of plastic money}

According to Bishty et al. (2015), customers' likes plastic money over cash money and the significant advantage that the card gives to the clients is the convenience and accessibility. The inclination to utilization of plastic money like Master card has its upsides and downsides with its convenience and moderateness (Subhani, 2011). Usage benefits might include the security, time saving, easy in carrying, travelling etc.

H1 Usage benefits significantly influence to the customers' positive view toward plastic money.

\section{ii. Financial benefits}

Credit cards additionally offer a few advantages to vendors. Shippers are generally paid in great assets inside 48 hours of presenting the exchange to their acquirers. In a U.S. overview, 83 percent of dealers said that their deals expanded and 58 percent said that their benefits expanded by tolerating Visas (Ernst \& Young, 1996). Some of the financial benefits might include savings, controlling expense, interest rate or service charge.

H2 Financial benefits significantly influence to the customers' positive view toward plastic money.

\section{iii. Shopping benefits}

Shoppers do online booking for both accommodation and satisfaction (Childers et al., 2001). Forsythe et al. (2006) mentioned that the built up a scale to gauge apparent advantages and dangers in web based shopping. Their investigation demonstrates that comfort, simplicity of shopping, and item choice (which are utilitarian advantages) represent bigger fluctuation clarified altogether apparent advantages in web based shopping, contrasted with the apparent epicurean advantage while shopping on the web. Thus, it tends to be derived that a person with higher utilitarian shopping intention is probably going to see more prominent advantages in internet shopping contrasted with another individual having lower utilitarian shopping thought processes. In terms of plastic money, shopping advantage includes higher price bulk of products and overseas shopping and many more.

H3 Shopping benefits significantly influence to the customers' positive view toward plastic money.

\section{iv. Convenience}

Thought of convenience for clients is long-standing, especially in the retailing and customer conduct literary works (Anderson, $1972 \&$ Kelley, 1958). Similarly, there is an affirmation of developing purchaser interest for convenience brought about by financial change, innovative advancement and escalating rivalry in business conditions (Berry et al., 2002; Seiders et al., 2000 \& Seiders et al., 2007) regardless of whether in on-or disconnected situations. When customers' purchasing power increases, transaction mode is safe and easy to use, this might provide convenience.

H4 Convenience significantly influence to the customers' positive view toward plastic money.

\section{v. Psychological factors}

Customarily, needs have been considered as a vehicle for the investigation of human inspiration (Oliver, 1997). To put it plainly, people always endeavor to accomplish a condition of security or then again homeostasis. This psychological state is upset when they are made mindful of a need. Along these lines, require and the want to fulfill it help to create the person's inspirations as for a particular activity (Goossens, 2000). Customers' psychology toward plastic money can be considered as how it adds value, whether it's fashionable or prestigious etc. 
H5 Psychological factors significantly influence customers' positive view toward plastic money.

\section{Research Methodology}

Sampling method: Convenient random sampling method has been adopted for selecting the respondents. People who use plastic money have been considered for the study. Respondents were contacted based on their online activeness.

Data collection method: A structured questionnaire has been prepared for data collection. Around 500 questionnaires have been sent to the respondents and 200 were returned with the response rate $40 \%$. All questionnaires were analyzed.

Analytical method: The objective of this study is to examine customers' perceptions about one of the technological adoptions in sustainable banking regarding plastic money. The quantitative research design fits to the study. As statistical analysis tools, factor analysis, descriptive statistics and regression analysis have been adopted for analyzing the research framework.

\section{Data analysis}

i. Demographic profile of the respondents: There was participation of diverse demographic profiled respondents to validate the data accumulation. Of the 200 respondents, there were $39.6 \%$ female and $60.4 \%$ male. The study was dominated by young people (age range 18-25, 26-35) and only $10 \%$ respondents were elderly. Such result indicates the usage of plastic money in Bangladesh is comprehensive among the young people.

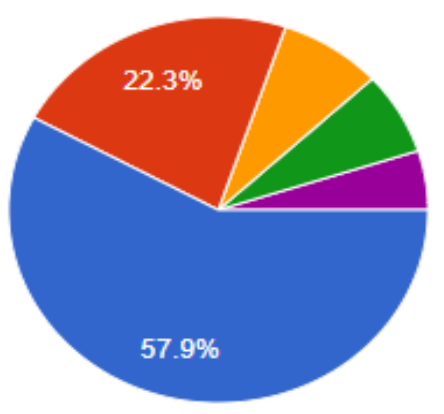

Figure 1. Income level of the respondents

Another important indication is that the plastic money usage is more prevalent among the lower-middle class people. There were about 58\% respondents in the study whose monthly income was below 25,000 BD taka shown in above figure 1.

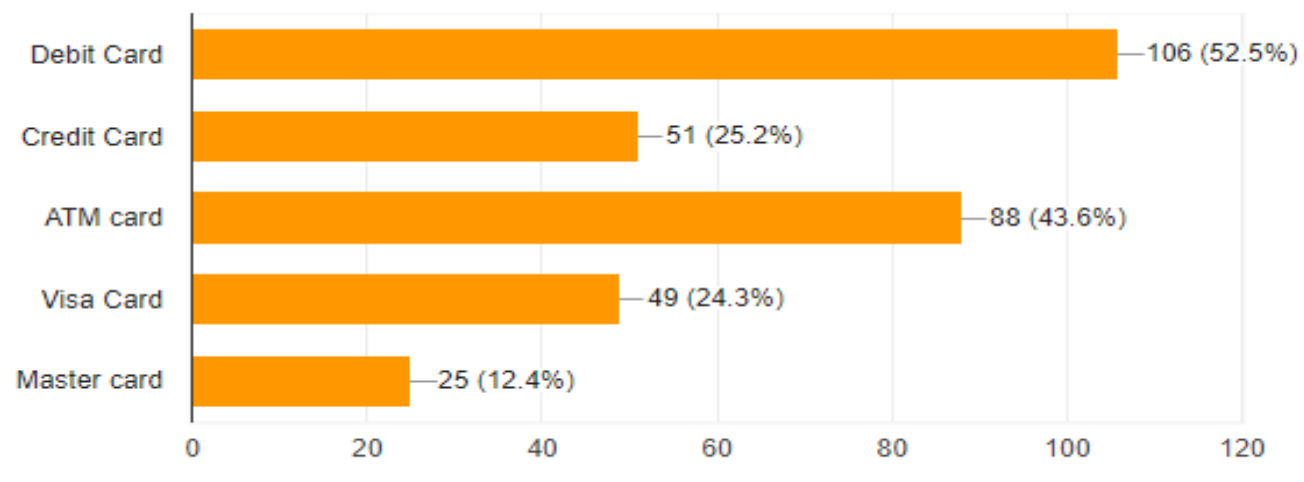

Figure 2. Type of card held by respondents

Above figure-2 shows that the most commonly used plastic card among the respondents is debit card (43.6\%), followed by ATM card, credit card, visa card and master card. Day-by-day the plastic use and its users are rapidly increasing in Bangladesh as people does not want to carry cash in their pocket for their own safety and security. 
ii. Factor analysis: The purpose of this confirmatory factor analysis is to support our premise in building these dimensions and the cohesion of the items creating them. Factor analysis now would support our proposition through few measures. The estimation method used in the analysis was R-type factor analysis. The analysis results indicated an acceptable overall suitability of factor analysis and the Kaiser-Meyer-Olkin measure of sampling adequacy was used to check for excessive correlations with a value equal to 0.717 (recommended value of KMO should be greater than 0.5) shows in table-1. This suggests the existence of small correlations between variables.

Table 1. KMO \& Bartlett's test

\begin{tabular}{lll}
\hline \multicolumn{2}{l}{ KMO and Bartlett's Test } & \\
\hline \multicolumn{2}{l}{ Kaiser-Meyer-Olkin Measure of Sampling Adequacy. } & .717 \\
\hline Bartlett's Test of Sphericity & Approx. Chi-Square & 390.698 \\
\cline { 2 - 3 } & Df & 36 \\
& Sig. & .000 \\
\hline
\end{tabular}

Finally, the estimated pattern matrix shown in below table-2, where items are distributed between 14 dimensions reduction.

Table 2. Principal Component Analysis by Kaiser Normalization

\begin{tabular}{|c|c|c|c|c|}
\hline \multicolumn{5}{|l|}{ Rotated Component Matrix ${ }^{a}$} \\
\hline & \multicolumn{4}{|c|}{ Component } \\
\hline & 1 & 2 & 3 & 4 \\
\hline 1. Increase Purchasing Power & -.077 & .221 & .205 & 677 \\
\hline 2. Easy To Use & .321 & -.134 & .187 & .696 \\
\hline Safest Mode & .523 & .127 & -.054 & .633 \\
\hline 4. Reasonable Interest Rate & -.069 & .743 & .213 & .319 \\
\hline 5. Risk Of Theft Minimized & .588 & .267 & .134 & .273 \\
\hline 6. Saves Time & .746 & .156 & .095 & .040 \\
\hline 7. Secure Transaction & .749 & .187 & .031 & .116 \\
\hline 8. Purchasing High Price Products & .078 & .189 & .821 & .156 \\
\hline 9. Purchasing Huge Size Products & .150 & .307 & .691 & .254 \\
\hline 10. Easy To Carry & .716 & -.204 & .342 & .009 \\
\hline 11. Ease Travelling Overseas & .582 & -.135 & .421 & .323 \\
\hline 12. Shopping Abroad & .490 & -.050 & .636 & -.011 \\
\hline 13. Easier To Control Expenditure & .170 & .841 & .137 & -.051 \\
\hline 14. Encourages To Save Money & .128 & .839 & .014 & .011 \\
\hline
\end{tabular}

Above table-2 clearly shows that the factor 1 has high coefficients for variables v5 (risk of theft minimized), v6 (saves time), v7 (security), v10 (easy to carry) and v11 (ease travelling). This factor may be labeled as a usage benefit factor. Similarly, factor 2 is highly correlated with the variables v4 (interest rate), v13 (controlling expenditure) and v14 (savings). This can be considered as financial benefit factor. Also, factor 3 has high coefficients in $\mathrm{v} 8$ (purchasing high price products), v9 (purchasing huge sized products) and v12 (shopping abroad) and this factor is labeled as shopping benefit factor. Lastly, factor 4 is highly related to v1 (increasing purchasing power), v2 (easy to use) and v3 (safest transaction mode) and thus factor 4 is labeled as convenience factor.

Test of hypothesis: The model is estimated through regression model and shows which dimensions significantly predict the customers' positive view to use plastic money in Bangladesh. The conceptual research model regressed all the independent variables (usage benefits, financial benefits, shopping benefits, convenience factor and psychological factor) on customers' positive view. Results in the coefficient table of regression shown in table-3.

Dependent variable: Positive view to plastic money usage

Table 3. Results of test of hypotheses between dependent and independent variables

\begin{tabular}{lllll}
\hline Independent Variable & T value & F & P value & $\mathbf{R}^{2}$ \\
\hline Usage benefits & 2.766 & 4.406 & .006 & .151 \\
Financial benefits & 2.002 & 2.235 & .047 & .059 \\
Shopping benefits & 1.260 & 3.253 & .221 & .105 \\
Convenience & 1.994 & 5.446 & .048 & .118 \\
Psychological factors & 7.309 & 4.665 & .000 & .208 \\
\hline
\end{tabular}

The $\mathrm{t}$-value is accepted when it is $>$ than 1.96. According to the regression coefficient table t-values of usage benefits, financial benefits, shopping benefits, convenience and psychological variables are accepted. 
Table 4. Summary results of test of hypotheses

\begin{tabular}{lll}
\hline Sl. & \multicolumn{1}{c}{ Hypotheses } & Results \\
\hline $\mathrm{H}_{1}$ & Usage benefits significantly influence to the customers' positive view toward plastic money & Supported \\
$\mathrm{H}_{2}$ & Financial benefits significantly influence to the customers' positive view toward plastic money. & Supported \\
$\mathrm{H}_{3}$ & Shopping benefits significantly influence to the customers' positive view toward plastic money. & Not \\
& & Supported \\
$\mathrm{H}_{4}$ & Convenience significantly influence to the customers' positive view toward plastic money. & Supported \\
$\mathrm{H}_{5}$ & Psychological factors significantly influence to the customers' positive view toward plastic money. & Supported \\
\hline
\end{tabular}

iii. Problems of plastic money: The total dimension means and standard deviations are shown in figure. All dimensions are measured in Likert scale measure ( 1 is strongly agree and 5 is strongly disagree).

Results indicate that the highest perceived dimension was fake notes at ATM (mean $=2.54)$ and the lowest dimension was higher service charge (mean = 2.21) (table- 5). Results indicate fake note at ATM and less worldwide access is highly problematic to the respondents, while all other dimensions are perceived moderately important to the sample.

The second issue is the dispute among respondents with respect to scarcity of taka at ATM, uncontrollable buying beyond budget and less worldwide access, where the standard deviation values are higher than other dimensions.

Table 5. Descriptive statistics of plastic money problems

\begin{tabular}{lccc}
\hline Descriptive Statistics & & & \\
\hline & $\mathrm{N}$ & Mean & Std. Deviation \\
\hline Few vendors & 200 & 2.36 & .838 \\
Less worldwide access & 200 & $\mathbf{2 . 5 1}$ & $\mathbf{1 . 0 0 7}$ \\
Damaged magnetic strap & 200 & 2.36 & .886 \\
Higher service charge & 200 & $\mathbf{2 . 2 1}$ & .917 \\
Mounting number of frauds & 200 & 2.39 & .843 \\
Technological complications & 200 & 2.25 & .946 \\
Fake notes at ATM & 200 & $\mathbf{2 . 5 4}$ & .997 \\
Scarcity of taka at ATM & 200 & 2.28 & $\mathbf{1 . 0 5 2}$ \\
Uncontrollable buying beyond budget & 200 & 2.25 & $\mathbf{1 . 0 1 0}$ \\
\hline
\end{tabular}

\section{Findings and Discussions}

From demographic information, this is observed that a large proportion of the sample belong to the young group and lower- middle class people. Majority of the respondents hold debit and ATM plastic card. The perceived advantages identified in research framework have been analyzed to examine customers' perceptions. There were four dimensions identified through factor analysis. These four factors have been labeled as four benefits of plastic money - usage benefits, financial benefits, shopping benefits and convenience advantages. Along with the four benefits of plastic money, psychological factors were also inspected through hypotheses testing. Psychological factors including prestigious, adds value, eases complex transaction and fashionable were analyzed. About $80 \%$ respondents were agreed to prestigious psychology, $82 \%$ agreed to add value, $79 \%$ agreed to ease complex transaction and $76 \%$ agreed to fashionable psychology.

To validate the research model, empirical test has been conducted using survey. Factor analysis was undertaken to show whether the dimensional items have been loading together and support the study premise. Results were positive and presented all the dimensions are significant in predicting the customers perceptions toward plastic money. For hypotheses testing, regression analysis was adopted. Results shown that except shopping benefits, all variables were significant. Usage benefits, financial benefits, shopping benefits and convenience factor significantly influence to the customers' positive view about plastic money.

Some problems of plastic cards have been identified. Most of the respondents agreed to the disadvantages they face while using the plastic cards. Descriptive statistics revealed that fake note at ATM and less worldwide access were highly challenging to the respondents.

\section{Conclusions}

Now-a-days, transactions over plastic money become easier as there is no need to have paper money. To conduct with the overseas shopping, usage of plastic money is increasing day by day. In Bangladesh, prevalence of plastic money usage starts from lower-middle class people and perceived advantages of plastic cards are similar to all people. There is positive view toward such technological adoption of sustainable banking. People do not need to think about the money they have or not, but to carry only a plastic chip into wallet. The findings disclose that customers' positive view towards plastic money is significantly influenced by usage benefits, financial benefits, shopping benefits and convenience factor. But shopping benefits can't influence positive view of 
customers. So, banks should undertake proper steps so that customers find shopping more useful by using plastic money. Some problems also have been identified in the card usage. Banks should also take note the problems customers face and initiate to take proper necessary steps to ensure sustainable and effective banking in Bangladesh.

\section{References}

Abdulla-Al-Mamun, M. (2010). Debit Card Use in Dhaka City: A Survey to Identify the Problems and Prospects, 333-334.

Anderson, W. T. (1972) 'Convenience Orientation and Consumption Behavior', Journal of Retailing 48 (Fall): 49-71.

Anderson, W. T. (1972). Convenience orientation and consumption behavior. Journal of Retailing, 48(3), 49.

Bennett, R. (1992). Marketing and competitive advantage, How to satisfy the customer, profitably. Bank Marketing, 24, 36-37.

Berry, L. L., Seiders, K., \& Grewal, D. (2002). Understanding service convenience. Journal of marketing, 66(3), 1-17. https://doi.org/10.1509/jmkg.66.3.1.18505

Bisht, A., Nair, P., Dubey, R., \& Hajela, T. (2015). Analysis of the use of plastic money: A boon or a bane. SIMS Journal of Management Research, 1 .

Childers, T. L., Carr, C. L., Peck, J., \& Carson, S. (2001). Hedonic and utilitarian motivations for online retail shopping behavior. Journal of retailing, 77(4), 511-535. https://doi.org/10.1016/S0022-4359(01)00056-2

Coldwell, J. (2001). Characteristics of a good customer satisfaction survey. Customer Relationship Management, 193-199.

Deviranjitha, S., \& S. Thamilarasan. (2014). "A Study on usage and satisfaction of credit cards by customers in Krishnagiri district." International Journal of Business and Administration Research Review", 160.

Diza, M., Munyanyi, W., \& Gumbo, L. (2017). Use of Plastic Money in Zimbabwe, Threats and Opportunities for Rural Communities. International Journal of Academic Research in Business and Social Sciences, 7(6), 354-366. https://doi.org/10.6007/IJARBSS/v7-i6/2968

Ernst \& Young (1996). "Survey of retail payment systems," Chain Store Age, January.

Forsythe, S., Liu, C., Shannon, D., \& Gardner, L. C. (2006). Development of a scale to measure the perceived benefits and risks of online shopping. Journal of interactive marketing, 20(2), 55-75. https://doi.org/10.1002/dir.20061

Goossens, C. (2000). Tourism information and pleasure motivation. Annals of tourism research, 27(2), 301-321. https://doi.org/10.1016/S0160-7383(99)00067-5

Gronroos, C. (1994). From marketing mix to relationship marketing: Towards a paradigm shift in marketing. Asia-Australia Marketing Journal, 2(1), 9-29. https://doi.org/10.1016/S1320-1646(94)70275-6

Gurpreet, K., \& Rashmi, S. (2017). Mrs. Plastic Money - A Way Forward for Cashless Transactions, IOSR Journal of Business and Management, 15-18. https://doi.org/10.9790/487X-1903031518

Hasan, S. A., Subhani, M. I., \& Osman, M. (2011). plastic money/credit cards charisma for now and then (A thin line between easy money and risky money).

Hugar, B. S., \& Basavaraj, C. S. (2014). A Study on Usage Pattern of Credit Cards in Gulbarga City. Asian Journal of Research in Banking and Finance, 4(11), 181-187. https://doi.org/10.5958/2249-7323.2014.01446.1

Jonker, N. (2007). Payment instruments as perceived by consumers-results from a household survey. De Economist, 155(3), 271-303. https://doi.org/10.1007/s10645-007-9062-1

Kelley, E. J. (1958). The importance of convenience in consumer purchasing. Journal of Marketing, 23(1), 32-38. https://doi.org/10.1177/002224295802300105

Khurana, S., \& Singh, S. P. (2011). An analytical study of customer's preferences and satisfaction in credit card industry. The IUP Journal of Bank Management, 10(1), 71-87.

Manivannan, P. (2013). Plastic money a way for cash less payment System. Global Research Analysis, 2, 10-12. https://doi.org/10.15373/22778160/January2013/84

Odusina, A. O. (2014). Automated Teller Machine usage and Customers Satisfaction in Nigeria. Global journal 
of Management and Business Research.

Oliver Richard, L. (1997). Satisfaction: A behavioral perspective on the consumer. New York ' NY: Irwin-McGraw-Hill.

Panagiotis, L., Athanasios, A., Dimitrios, K., Zacharias, D., \& Eleni, K. (2018). The Benefits of Use of Plastic Money in Greece and the EU: Case Study of Use of Plastic Money from the Elderly. Theoretical Economics Letters, 8(05), 793. https://doi.org/10.4236/tel.2018.85055

Ramasamy, S. R., Guru, B. K., Nair, M., \& Vaithilingam, S. (2006). Development of E-money in Malaysia. In National Statistics Conference, Putrajaya International Convention Centre, Putrajaya, Malaysia.

Seiders, K., Berry, L. L., \& Gresham, L. G. (2000). Attention, retailers! How convenient is your convenience strategy?. MIT Sloan Management Review, 41(3), 79.

Seiders, K., Voss, G. B., Godfrey, A. L., \& Grewal, D. (2007). SERVCON: development and validation of a multidimensional service convenience scale. Journal of the academy of Marketing Science, 35(1), 144-156. https://doi.org/10.1007/s11747-006-0001-5

Sudhakar, G. (2014). Plastic Money: The Rise of E-Money. A Monthly Double-Blind Peer Reviewed Refereed Open Access International e-Journal.

Sumi, F. R., \& Safiullah, A. B. (2014). Problems and Prospects of Plastic Money in Bangladesh. IOSR Journal of Business \& Management, 16 (12), 31-38. https://doi.org/10.9790/487X-161223138

\section{Copyrights}

Copyright for this article is retained by the author(s), with first publication rights granted to the journal.

This is an open-access article distributed under the terms and conditions of the Creative Commons Attribution license (http://creativecommons.org/licenses/by/4.0/). 